Dear Author,

Please, note that changes made to the HTML content will be added to the article before publication, but are not reflected in this PDF.

Note also that this file should not be used for submitting corrections. 


\title{
Cu-nanoparticles ecotoxicity - Explored and explained?
}

\author{
Susana I.L. Gomes ${ }^{\mathrm{a}, *}$, Michael Murphy ${ }^{\mathrm{b}}$, Margrethe T. Nielsen ${ }^{\mathrm{c}}$, Søren M. Kristiansen ${ }^{\mathrm{c}}$, \\ Mónica J.B. Amorim ${ }^{\mathrm{a}}$, Janeck J. Scott-Fordsmand ${ }^{\mathrm{d}}$ \\ a Department of Biology \& CESAM, University of Aveiro, 3810-193 Aveiro, Portugal \\ ${ }^{\mathrm{b}}$ HASYLAB, DESY, Nokestraße 85, 22607 Hamburg, Germany \\ ${ }^{\mathrm{c}}$ Department of Earth Sciences, Aarhus University, Høegh-Guldbergs Gade 2, DK-8000 Aarhus, Denmark \\ d Department of Bioscience, Aarhus University, Vejlsovej 25, PO Box 314, DK-8600 Silkeborg, Denmark
}

\section{H I G H L I G H T S}

- Exposure to various $\mathrm{Cu}$ materials caused different effect

concentrations.

- Detailed in soil exposure

characterization was performed.

- The characterization included XAS

and Sequential Extraction.

- The analyses indicate NPs were partly, i.e. not fully oxidized in soils.

- Effects could be related to both

toxicity of release of ions and of particles.

\section{A R T I C L E I N F O}

\section{Article history:}

Received 21 January 2015

Received in revised form 10 June 2015

Accepted 21 June 2015

Available online $\mathrm{xxxx}$

\section{Keywords:}

Copper nanoparticles

XANES

Soil

Enchytraeus crypticus

Oligochaeta

\section{G R A P H I C A L A B S T R A C T}

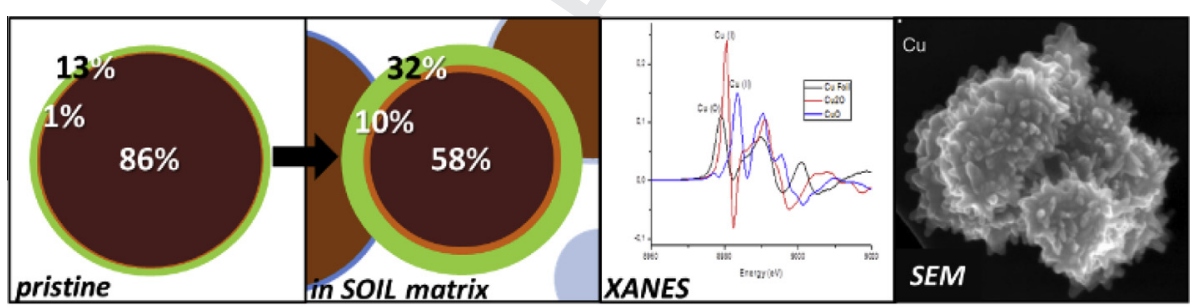

$\square \mathrm{Cu}^{0} \square \mathrm{Cu}^{1+} \square \mathrm{Cu}^{2+}$

\begin{abstract}
A B S T R A C T
The nano-form of copper (Cu-NPs) is already extensively used. In this paper the toxic effect of $\mathrm{Cu}$ in the worm Enchytraeus crypticus (Oligochaeta: Enchytraeidae) was assessed following exposure to (1) Cu-salt: freshly spiked soil with copper-nitrate, (2) Cu-NPs: freshly spiked soil with Cu nanoparticles (80 nm), and (3) Cu-field: historically Cu contaminated soil ( 80 years ago). Our main aims were to compare the three different exposure regimes and respective toxicity, and to determine how the oxidation state of the Cu and dissolution state of the particles differed. Characterization of in situ-exposure included identification of oxidation states with synchrotron generated X-ray absorption near-edge spectroscopy (XANES) analysis, activity of free $\mathrm{Cu}^{2+}$ in soil-solution (Ion Selective Electrode), and the relative distribution of the labile $\mathrm{Cu}$-fractions (Sequential Extraction). Freshly spiked $\mathrm{Cu}$-salt was the most toxic for reproductive output of the worms, followed by $\mathrm{Cu}-\mathrm{NPs}$ and then $\mathrm{Cu}$-field. XANES indicated only one oxidation state (II) in Cu-salt and Cu-field soil, whereas in Cu-NPs soil it was present in all oxidation states (0, I and II). The partial oxidation of the Cu-NPs (in soil) was evident and with limited dissolution.
\end{abstract}

(C) 2015 Published by Elsevier Ltd.

\section{Introduction}

$\mathrm{Cu}$ nanoparticles (Cu-NPs) are already extensively used as wood-preservatives e.g. estimated to constitute $50 \%$ of the $\mathrm{Cu}$ containing wood-preservatives on the North American market (79.000 tonnes valued at $\$ 4.9$ billion, see Evans et al. (2008)). The

\footnotetext{
* Corresponding author.

E-mail address: susana.gomes@ua.pt (S.I.L. Gomes).
}

North America market represents 50\% of the global market. Additional future sources may be $\mathrm{Cu}-\mathrm{NPs}$ containing fertilizers and food additives/packaging (Batsmanova et al., 2013; Belli, 2012; Llorens et al., 2012). Hence, based on the above, direct exposure and hotspot scenarios in soils is very likely.

Copper toxicity is well documented to soil-dwelling organisms, e.g. enchytraeids (Amorim et al., 2008, 2005; Maraldo et al., 2006; Menezes-Oliveira et al., 2011), but very little is known about $\mathrm{Cu}-\mathrm{NPs}$. So far, only a handful studies reported effects of Cu-NPs 
via soil-exposure. Heckmann et al. (2011) observed that Cu-salt was more toxic (survival and reproduction) than Cu-NPs to the earthworm Eisenia fetida. Unrine et al. (2010), also using E. fetida, observed metallothionein induction following exposure to Cu-NPs (34 nm and $102 \mathrm{~nm}$, TEM estimation) contaminated soil. Gomes et al. (2012a,b), using enchytraeids (Enchytraeus albidus), observed that both $\mathrm{Cu}$-salt and $\mathrm{Cu}-\mathrm{NPs}$ exposure caused oxidative stress and differential gene-expression, with different response-patterns for $\mathrm{Cu}-\mathrm{NPs}$ and for $\mathrm{Cu}$-salt. The same species indicated that $\mathrm{Cu}-\mathrm{NPs}$ affected reproduction and avoidance to a higher extent than Cu-salt (Amorim and Scott-Fordsmand, 2012). Finally, Amorim et al. (2012), also using E. albidus, observed no differences in energy-reserves (lipids, proteins and carbohydrates) following exposure to $\mathrm{Cu}$-salt or $\mathrm{Cu}-\mathrm{NPs}$.

Our aim here is to study the Cu toxicity to Enchytraeus crypticus between three exposure regimes, i.e. Cu-NPs spiked soil, Cu-salt spiked soil, and soil $\mathrm{Cu}$-contaminated in the field 80 years ago (Cu-field) (Scott-Fordsmand et al., 2000a). Toxicity is measured as survival and reproductive-output. To help explain the difference in toxicity exposure is characterized as total $\mathrm{Cu}$ concentration, the labile concentration, the free $\mathrm{Cu}^{2+}$ concentration in the soil-solution, and in supplement to this the $\mathrm{Cu}$ oxidation state is measured in the soil.

E. crypticus (Enchytraeidae, Oligochaeta) was used; this is a standardized species (ISO, 2005; OECD, 2004), hence comparable to other studies. Enchytraeids inhabit the litter layer and the upper mineral soil where they feed on fungal hyphae, microorganisms and dead organic matter (OM) (Jansch et al., 2005; Løkke and Van Gestel, 1998). Further they actively contribute to the acceleration of OM decomposition and nutrient recycling processes. As a soft-bodied soil living invertebrate, uptake is made not only via ingestion (e.g. food and soil particles) but also via the body surface or skin (used for respiration and water uptake) (Peijnenburg et al., 2012).

\section{Material and methods}

\subsection{Experimental plan}

To study the $\mathrm{Cu}$ toxicity, three $\mathrm{Cu}$ forms were used, i.e. $\mathrm{Cu}-\mathrm{NPs}$ spiked soil, Cu-salt spiked soil, and Cu-contaminated soil from the field 80 years ago ( $\mathrm{Cu}$-field). The $\mathrm{Cu}$-exposure concentrations aimed to cover the full concentration-response (reproductive output) curve for the organisms. Since difference in toxicity between the three $\mathrm{Cu}$ forms was observed in range-finding experiments, the exposure-concentrations were adjusted accordingly. Biological and physicochemical measurements were performed (see sections ahead).

\subsection{Test soil}

Test soil was collected at Hygum, Jutland, Denmark. The general physicochemical characteristics of the soil from the Hygum-site are as follows: $20-32 \%$ coarse sand $(>200 \mu \mathrm{m}), 20-25 \%$ fine sand (63-200 $\mu \mathrm{m}), 11-20 \%$ coarse silt $(20-63 \mu \mathrm{m}), 12-20 \%$ silt $(20-20 \mu \mathrm{m}), 12-16 \%$ clay $(<2 \mu \mathrm{m}), 3.6-5.5 \%$ organic matter, Cation Exchange Capacity 6.8-10 (cmolc/kg dw), N $0.25-0.31 \%$ and $\mathrm{P}$ 0.10-0.12\%. The clay mineralogy analyzed by X-ray diffraction were dominated by illite, kaolinite, chlorite and vermiculite.

Previous (more than 80 years ago), this site was a timber preservation site using copper sulphate to preserve and consequently contaminating the soil. There is a known contaminated gradient of $\mathrm{Cu}$, ranging from the natural background levels of thousands of $\mathrm{mg} \mathrm{Cu} / \mathrm{kg}$ dry soil (Scott-Fordsmand et al., 2000a).
For the experiments, soil was sampled in the field to a depth of $20 \mathrm{~cm}$. To exclude existing soil animals, major stones and plant material, the soil was dried at $80^{\circ} \mathrm{C}$ for $24 \mathrm{~h}$ in an oven (Memmert, Type UL40, Braunschweig, Germany) and then sieved to $<2 \mathrm{~mm}$. Besides the control soil (with background $\mathrm{Cu}$ levels), the field test soil included $\mathrm{Cu}$ concentrations of 525, 1155, 2880 and $3900 \mathrm{mg} \mathrm{Cu} / \mathrm{kg}$, as picked from different locations along the field gradient and measured by flame Atomic Absorption Spectrometry (AAS). The physicochemical parameters (described above) vary little with increasing $\mathrm{Cu}$ concentrations; the only monotonic trend observed was for the organic matter, 3.6-5.5\% positively correlating with the $\mathrm{Cu}$ content.

In the experiment, the control soil was spiked with $\mathrm{Cu}$-salt or $\mathrm{Cu}-\mathrm{NPs}$, and the field soil with original concentrations. For the $\mathrm{Cu}$-salt spiked soil the $\mathrm{pH}$ was regulated (with $\mathrm{CaCl}_{2}$ ) to 6.5. During the experiment the soil $\mathrm{pH}$ was measured at the beginning (day 0 ) and at the end of the experiment ( 3 weeks).

\subsection{Test chemicals and characterization}

Compounds used included Cu-salt: copper (II) nitrate trihydrate $\left(\mathrm{Cu}\left(\mathrm{NO}_{3}\right)_{2} \cdot 3 \mathrm{H}_{2} \mathrm{O}\right)$ ( $\geqslant 99 \%$ pure, Merck, Darmstadt, Germany) and Cu-NPs: elemental $\mathrm{Cu}$ (nominal particle size $80 \mathrm{~nm}$ ) without coating (American Elements). The particles were characterized (see Heckmann et al., 2011) by transmission electron microscopy TEM (Phillips/FEI, Eindhoven, The Netherlands), scanning electron microscopy - SEM (FEI NOVA 600, FEI Company, Hillsboro USA), powder X-ray diffraction - PXRD (STOE STAPI PSTOE \& Cie $\mathrm{GmbH}$, Darmstadt, Germany) and dynamic light scattering - DLS (Malvern Zetasizer Nano, Malvern Instruments Ltd, Worcestershire, UK).

Oxidations states, of pure particles and mixed in soil, were analyzed by X-ray absorption near edge structure (XANES) measurements, performed at Beamlines $\mathrm{C}$ and $\mathrm{X} 1$ at DORIS (DESY, Hamburg, Germany) using a Si (111) crystal pair monochromator for the Cu energy range with a resolution $\Delta E / E$ of $<10^{-4}(<1 \mathrm{eV})$. Powder Standards were mixed with cellulose and pressed into pellets of $13 \mathrm{~mm}$ in diameter with $\sim 2$ absorption lengths of material ensuring sufficient uniformity and thickness for transmission measurements. Soil samples (three replicates) were sealed in Kapton tape and measured in fluorescence mode using a Canberra 7 element solid state $(\mathrm{Ge})$ detector to monitor the $\mathrm{Cu} \mathrm{K} \alpha$ fluorescence line. Spectra were normalized to the incoming flux and a uniform edge step. Background subtraction, normalization and linear combination analysis of the spectra was performed using Athena (Ravel and Newville, 2005). To enhance resolution the soil samples contained $3000 \mathrm{mg} \mathrm{Cu} / \mathrm{kg}$ soil (spiked), similar but lower resolution spectra (not shown) were obtained at lower soil Cu concentrations.

To verify exposure, the total soil $\mathrm{Cu}$-concentrations were analyzed by AAS (Perkin Elmer 4100, Ueberlingen, Germany). The AAS analyses were checked using a standard reference sample (standard oyster tissue (NBS 1566a Oyster Tissue, U.S. Department of Commerce, National Bureau of standards, Gaithersburg, MD 20899)). The soil (1 g dry weight) was digested using $7 \mathrm{~N} \mathrm{HNO}_{3}$ and heating up to $110{ }^{\circ} \mathrm{C}$ until all brown fumes were gone (Scott-Fordsmand et al., 2000b).

To estimate the labile $\mathrm{Cu}$ fraction two concurrent experiments were performed. For these experiments the labile $\mathrm{Cu}$-fractions were estimated by measures of free active $\mathrm{Cu}^{2+}$ in soil-solution and estimating the distribution of $\mathrm{Cu}$ between the various soil fractions using sequential extraction of $\mathrm{Cu}$ from soil. The free Cu-activity $\left(\mathrm{Cu}^{2+}\right)$ was measured on soil-solutions using an ion-selective electrode (ISE25CU, Radiometer) see (Gomes et al., 2012a). The soil-solution extract was the supernatant of a (1:5) soil:water solution which was mixed for $5 \mathrm{~min}$ at $250 \mathrm{rpm}$ (lab shaker) and then settled for $2 \mathrm{~h}$. This soil-solution contained other 
elements that possibly could interfere with the ISE measures, hence to support the soil-water observations, the possible dissolution of the $\mathrm{Cu}-\mathrm{NPs}$ was measured in a simpler solution, a modified-water solution. The modified-water solution was demineralized water with the same ionic strength and $\mathrm{pH}$ as soil-solution extracts, by adding $\mathrm{KNO}_{3}$ to the demineralized water. The distribution between soil fraction was estimated by sequential extraction following the Rauret et al. (1999) modifications of the BCR-method. In short, 1 st extraction: $0.11 \mathrm{M}$ acetic acid [targeting carbonates], 2nd extraction: $0.5 \mathrm{M}$ hydroxylammonium chloride [to dissolve Mn-and Fe-oxides], and the 3rd extraction: $8.8 \mathrm{M}$ hydrogen-peroxide plus heating [to digest organic matter] followed by $1.0 \mathrm{M}$ ammonium acetate [to complex re-adsorbed $\mathrm{Cu}$ ]. The extraction analyses were performed on $1.3 \mathrm{~g}$ dry soil at the exposures scenario similar to that of the XANES analyses. The extracted fractions were analyzed for $\mathrm{Cu}$ on AAS (as described above).

\subsection{Test organism}

The test organism used for this was the specie E. crypticus, Westheide and Graefe 1992. Individuals were cultured in Petri dishes containing agar medium, consisting of a sterilized mixture of four different salt solutions $\left(\mathrm{CaCl}_{2} \cdot 2 \mathrm{H}_{2} \mathrm{O} ; \mathrm{MgSO}_{4} ; \mathrm{KCl} ; \mathrm{NaHCO}_{3}\right)$ and a Bacti-Agar medium (Oxoid, Agar No. 1), kept at $20^{\circ} \mathrm{C}$ and fed on dried, ground oats.

\subsection{Spiking procedure}

Spiking of uncontaminated field collected soil was done according to OECD recommendations for the testing of non-soluble substances (OECD, 2004). In short, the equivalent of $2.5 \mathrm{~g}$ of dry soil per test vessel ( $10 \mathrm{~g}$ per treatment) was mixed with the required quantity of the test substances (Cu-salt or Cu-NPs), as dry powders, to obtain the desired final concentrations. This portion of spiked soil was added to the remaining pre-moistened soil (20\% of water) and mixed manually for $10 \mathrm{~min}$. The procedure was repeated for each test concentration and the soil was then divided into 4 replicates per treatment. The spiked concentrations used were 100,200 , 400, 600, 800, 1000 and $1500 \mathrm{mg} \mathrm{Cu} / \mathrm{kg}$ for Cu-salt and 100, 400, 800,1000 and $1500 \mathrm{mg} \mathrm{Cu} / \mathrm{kg}$ for Cu-NPs.

\subsection{Test procedure}

Test procedures followed the Enchytraeid Reproduction Test (ERT) (OECD, 2004). In short ten adult organisms with well-developed clitellum and similar size were selected and introduced in each test vessel containing $25 \mathrm{~g}$ of moist soil and fed with $25 \mathrm{mg}$ of finely ground and autoclaved rolled oats. The vessels were covered with a lid containing small holes and the test ran for 3 weeks, at $20^{\circ} \mathrm{C}$ and $16: 8 \mathrm{~h}$ photoperiod. Four replicates per treatment were used. Weekly, $12.5 \mathrm{mg}$ of food was supplied and soil moisture was adjusted by replenishing weight loss with the proper amount of demineralized water. At the test end enchytraeids were extracted by spreading the soil of each test vessel into plastic containers $(200 \mathrm{ml}$ volume and diameter of $7 \mathrm{~cm}$ ), which were filled with demineralized water, gently shaken and left for $24 \mathrm{~h}$ at $5{ }^{\circ} \mathrm{C}$ for sedimentation to occur. After that, adult and juvenile enchytraeids appeared on the soil surface and were collected and counted under dissection microscope within $24 \mathrm{~h}$ to assess their survival and reproduction.

\subsection{Statistics}

Results were analyzed trough a one-way ANOVA (Dunnett's Method) (SigmaPlot 11.0) to assess differences between control and treatments and to determine the No Observed Effect Concentration (NOEC) and the Lowest Observed Effect Concentration (LOEC) as the highest tested concentration with no statistically significant effect and the lowest tested concentration with a statistically significant effect, respectively. The reproduction effect concentrations $\left(\mathrm{EC}_{x}\right)$ and the lethal concentration to $50 \%$ of the organisms $\left(\mathrm{LC}_{50}\right)$, were calculated using the Toxicity Relationship Analysis Program (TRAP). For the $\mathrm{LC}_{50}$ probit was used and for the $\mathrm{EC}_{x}$ determination a 2-parameters non-linear sigmoid threshold model was used.

\section{Results}

\subsection{Particles characterization}

The tested nanoparticles (American elements) had a mean nominal diameter of $80 \mathrm{~nm}$ and purity of $99.5 \%$. Measured by PXRD the crystal particle size was $\geqslant 66 \mathrm{~nm}$ with a $z$-average of $419 \pm 1 \mathrm{~nm}$ (measured by DLS) indicating agglomeration of particles, and a Zeta potential of $15.3 \pm 0.3 \mathrm{mV}$ (measured in demineralized water). Correspondence between the $\mathrm{Cu}$ and $\mathrm{CuO}$ crystallite sizes and the TEM and SEM images, suggest that the particle morphology was comprised by a $\mathrm{Cu}$ crystalline core with a $\mathrm{Cu}_{x} \mathrm{O}_{y}$ (shell) surface oxidation (Heckmann et al., 2011), see Supplementary data (Table S1, Fig. S1A/B, and S2).

\subsection{Exposure characterization}

The soil "background" $\mathrm{Cu}$ concentration was $30 \mathrm{mg} \mathrm{Cu} / \mathrm{kg}$. For all test-exposures the total concentration was within $5-7 \%$ of the nominal (i.e. "background" plus added $\mathrm{Cu}$ ). The $\mathrm{pH}$ of the soil remained constant throughout the experiments.

\subsubsection{XANES characterization (Cu oxidation states)}

The XANES (using linear combination fit (LCF) in the program Athena (Ravel and Newville, 2005)) indicated that oxidation state distribution of Cu-NPs before addition to soil was approximately $86 \% \mathrm{Cu}(0), 1 \% \mathrm{Cu}(\mathrm{I})$ and $13 \% \mathrm{Cu}(\mathrm{II})$ (Table $\mathrm{S} 1$ ). For the Cu-NPs spiked soil, oxidation state distribution was approximately $58-59 \% \mathrm{Cu}(0), 10 \% \mathrm{Cu}(\mathrm{I})$ and $32 \% \mathrm{Cu}(\mathrm{II})$, based upon analysis of a soil containing $3000 \mathrm{mg} \mathrm{Cu}-\mathrm{NPs} / \mathrm{kg}$ soil (Fig. 1 and Table 1, see also Supplementary data). For the $\mathrm{Cu}$-salt and Cu-field contaminated soils, XANES showed that only the oxidation state $\mathrm{Cu}(\mathrm{II})$ could be observed. For Cu-NPs spiked soil the "background" soil Cu concentration (approx. $30 \mathrm{mg} \mathrm{Cu} / \mathrm{kg}$ ) explained $1 \%$ of the oxidation state. The XANES spectra indicate that $\mathrm{Cu}(\mathrm{II})$ mainly exists as $\mathrm{Cu}-\mathrm{O}$ bonds (although not possible to exclude $\mathrm{N}$ bounds). For both the $\mathrm{Cu}$-salt and the $\mathrm{Cu}$-field the indications are also of $\mathrm{Cu}-\mathrm{O}$ bonds (or $\mathrm{N}$ ).

\subsubsection{Ion selective electrode ( $\mathrm{Cu}^{2+}$ activity)}

The active $\mathrm{Cu}^{2+}$ fraction (as measured by Cu-ISE) in modified-water and the soil-solution extracts was below the detection limit and quantification $\left(3 * 10^{-9} \mathrm{M} \mathrm{Cu}^{2+}\right)$. The detection limit corresponded to that less than $5 * 10^{-7} \%$ of the total-content that could be detected.

\subsubsection{Sequential extraction characterization (Cu binding)}

The sequential extraction (Fig. 2) showed nearly similar extraction patterns for the $\mathrm{Cu}$-NPs and the $\mathrm{Cu}$-salt samples, with approximate values of $69 \%$ (Cu-NPs) and $77 \%$ (Cu-salt) in the first extraction, 28\% (Cu-NPs) and 22\% (Cu-salt) in the second extraction, $3 \%$ (both) in the third extraction, and less than $1 \%$ (both) in the residues. For the field-contaminated soil the equivalent \% was: 1 st extraction $34 \%$, 2nd extraction $40 \%$, 3rd extraction $13 \%$ 

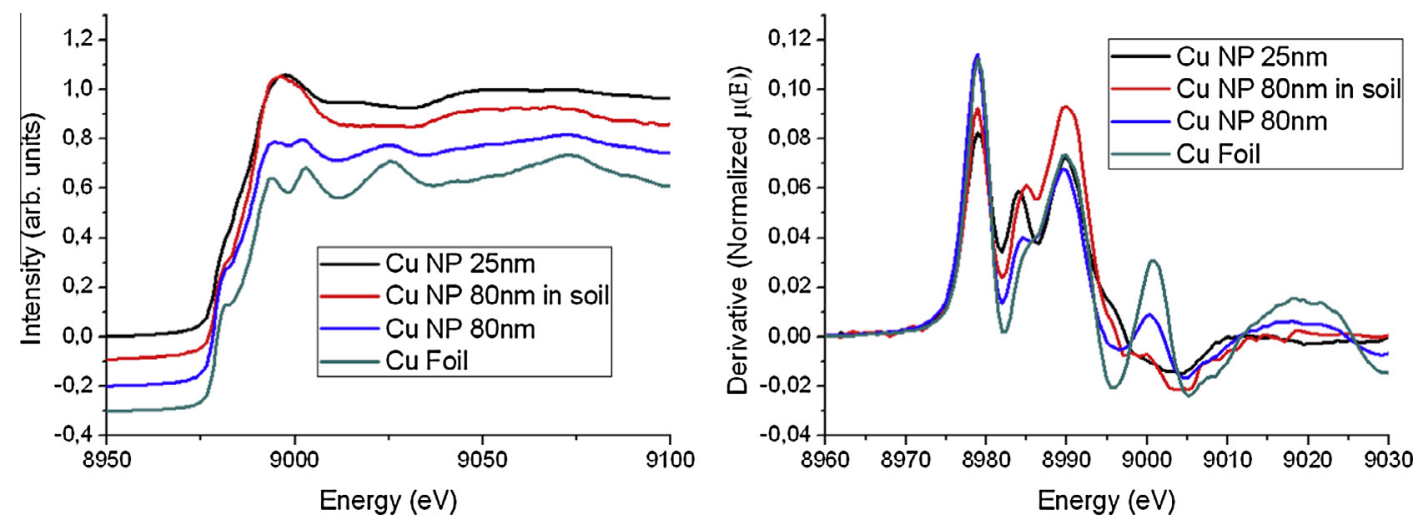

Fig. 1. Left, normalized XANES spectra at the $\mathrm{Cu}$ K-edge. Right, 1 st derivative of the normalized XANES spectra.

Table 1

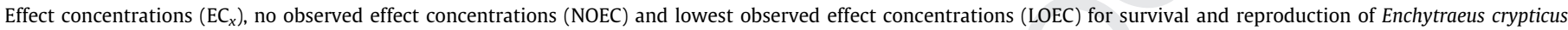
exposed to $\mathrm{Cu}\left(\mathrm{NO}_{3}\right)_{2}$ (Cu-salt), copper nanoparticles (Cu-NPs) and Cu field historically contaminated soil (Cu-field). NE: No Effect.

\begin{tabular}{|c|c|c|c|c|c|c|c|}
\hline & \multicolumn{2}{|l|}{ Survival } & \multicolumn{5}{|l|}{ Reproduction } \\
\hline & $\mathrm{LC}_{50}$ & NOEC/LOEC & $\mathrm{EC}_{10}$ & $\mathrm{EC}_{20}$ & $\mathrm{EC}_{50}$ & NOEC/LOEC & Steepness (SE) $\mathrm{Y}_{0}$ \\
\hline Cu-salt & $595(555-653)$ & $400 / 600$ & $254(150-358)$ & $290(211-369)$ & $361(326-398)$ & $200 / 400$ & $5.1 * 10^{-3}\left(1.8 * 10^{-3}\right) 239$ \\
\hline Cu-NPs & $\mathrm{NE}$ & $>1500$ & $590(-29-1208)$ & $982(575-1389)$ & $1760(1038-2482)$ & $>1500$ & $4.7 * 10^{-4}\left(2.1 * 10^{-4}\right) 227$ \\
\hline $\mathrm{Cu}$-field & $3508(3292-3726)$ & $2880 / 3990$ & $\mathrm{NE}$ & $564(-352-1482)$ & $2068(1391-2747)$ & $<525$ & $2.4 * 10^{-4}\left(0.6 * 10^{-4}\right) 224$ \\
\hline
\end{tabular}

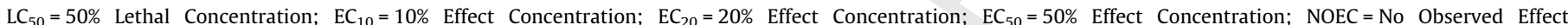
Concentration; LOEC = Lowest Observed Effect Concentration; 95\% CL = 95\% Confidence Limits; NE: No Effect;

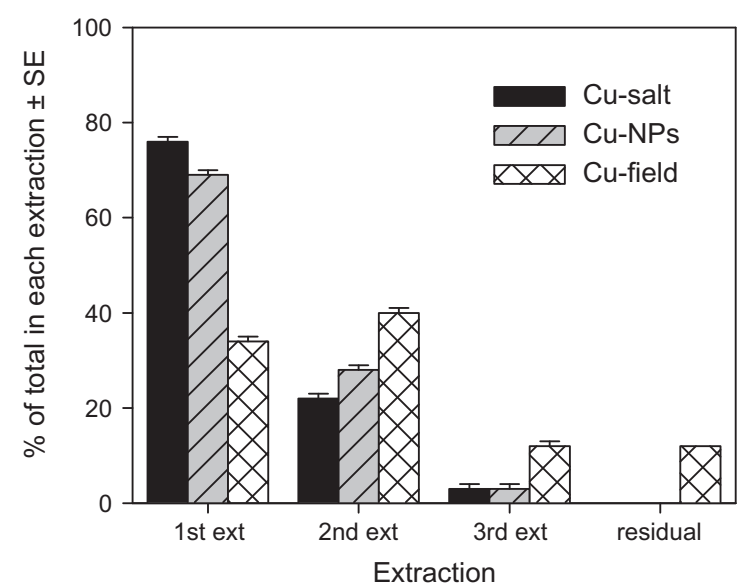

Fig. 2. Relative distribution between fractions from sequential extraction of copper from Hygum-soil contaminated with $2000 \mathrm{mg} / \mathrm{kg}$ of $\mathrm{Cu}\left(\mathrm{NO}_{3}\right)_{2}$ (Cu-salt), copper nanoparticles (Cu-NPs) and $\mathrm{CuSO}_{4}$ historical contamination (Cu-field).

and $12 \%$ in the residual. Technically speaking, the 1 st extraction targets exchangeable and acid soluble $\mathrm{Cu}$, the 2nd extraction the reducible $\mathrm{Cu}$, and the 3rd extraction targets the oxidisable $\mathrm{Cu}$ in the soil sample.

The chemical exposure analyses (3.2.1-3.2.3) showed a partial dissolution of the nano-form (XANES), and that for the $\mathrm{CuNO}_{3}$ and the $\mathrm{Cu}-\mathrm{NPs}$ exposure $\mathrm{Cu}$ was bound primarily in the exchangeable and acid soluble part (i.e. assumed to be "more easily" available), whereas a higher fraction of the $\mathrm{Cu}$ in the Cu-field exposure was bound in the reducible and oxidisable fraction of the soil (i.e. "more hardly" available). Since, the $\mathrm{Cu}^{2+}$ activity (ISE measures) was very low in all soils, is seem that virtually all $\mathrm{Cu}$ was bound to soil surfaces. The picture (see Fig. 3) seem to be that for $\mathrm{CuNO}_{3}$ and $\mathrm{Cu}-\mathrm{NPs}$ a large fraction of the $\mathrm{Cu}$ is bound "loosely" to soil surfaces, with Cu-NPs remaining on the particulate form, whereas for the $\mathrm{Cu}$-field soil the $\mathrm{Cu}$ is incorporated into less extractable sites (see Fig. 4).

\subsection{Effect characterization}

All the tests fulfilled the biological validity-criteria as described in the OECD guideline, i.e. controls mortality $<20 \%$, number of juveniles $>25$ and coefficient of variation $<50 \%$. The soil $\mathrm{pH}$ was not significantly different between test conditions and did not significantly change during the test duration.

Survival was affected by $\mathrm{Cu}$-salt and Cu-field treatments, but not by $\mathrm{Cu}-\mathrm{NPs}$ (Table 1, Fig. 3); reproduction was affected by all $\mathrm{Cu}$ materials. All effect scenarios showed a continuous concentration-response relationship. The freshly spiked $\mathrm{Cu}$-salt caused an $\mathrm{LC}_{50}$ of $595 \mathrm{mg} \mathrm{Cu} / \mathrm{kg}$ (adult-survival) and an $\mathrm{EC}_{50}$ at $361 \mathrm{mg}$ $\mathrm{Cu} / \mathrm{kg}$ (reproductive output). The $\mathrm{Cu}-\mathrm{NPs}$ caused an $\mathrm{EC}_{50}$ at $1760 \mathrm{mg} \mathrm{Cu} / \mathrm{kg}$ (reproductive output), which was similar for the historically $\mathrm{Cu}$-contaminated field soil (Cu-field) i.e. the $\mathrm{EC}_{50}$ was $2068 \mathrm{mg} \mathrm{Cu} / \mathrm{kg}$. For Cu-field adult survival was affected $\left(\mathrm{LC}_{50}\right)$ at $3508 \mathrm{mg} \mathrm{Cu} / \mathrm{kg}$ (Table 1).

\section{Discussion}

This study showed that in a 21-day test the Cu toxicity to the soil organism E. crypticus depended on the $\mathrm{Cu}$-form, with up to a sixfold difference in toxicity level among the three exposure regimes: $\mathrm{CuNO}_{3}$ (most toxic), followed by $\mathrm{Cu}$-nanoparticles (Cu-NPs) and Cu-field soil (Cu-field) exposure. The chemical exposure analyses show that for $\mathrm{CuNO}_{3}$ and $\mathrm{Cu}-\mathrm{NPs}$ a large fraction of the $\mathrm{Cu}$ is bound "loosely" to soil surfaces, with $\mathrm{Cu}-\mathrm{NPs}$ remaining on the particulate form, whereas for the $\mathrm{Cu}$-field soil the $\mathrm{Cu}$ is incorporated into less extractable sites. Hence, this sixfold toxicity difference observed between $\mathrm{CuNO}_{3}$ exposure and the $\mathrm{Cu}-\mathrm{NPs}$ and $\mathrm{Cu}$-field, seemed to be partially due to a difference in available $\mathrm{Cu}$ 
CuNO3

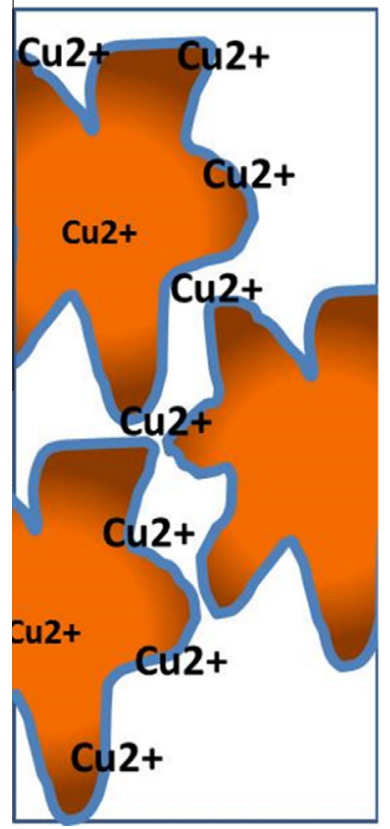

Cu-NPs

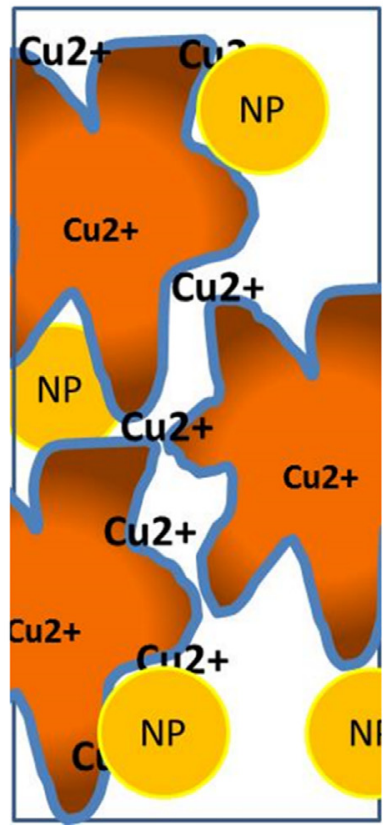

Cu-Field

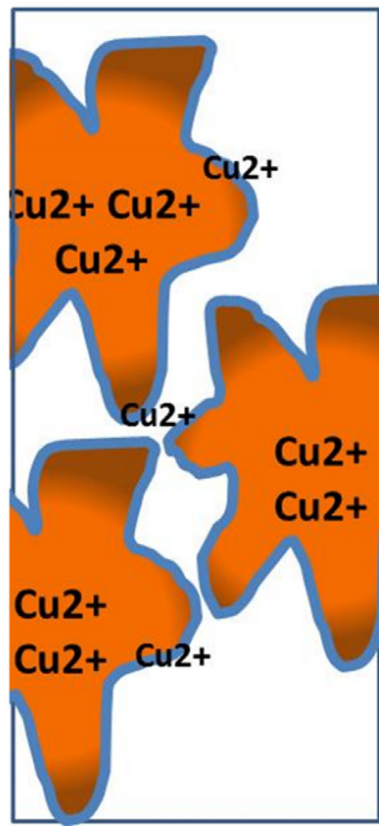

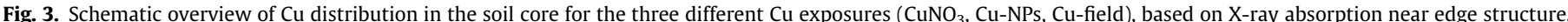

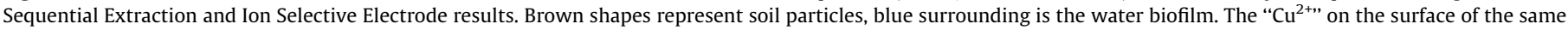

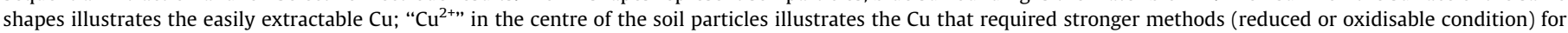

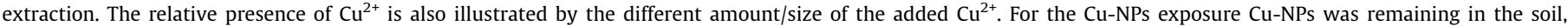

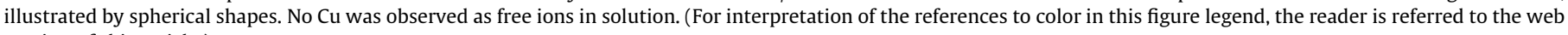
version of this article.)
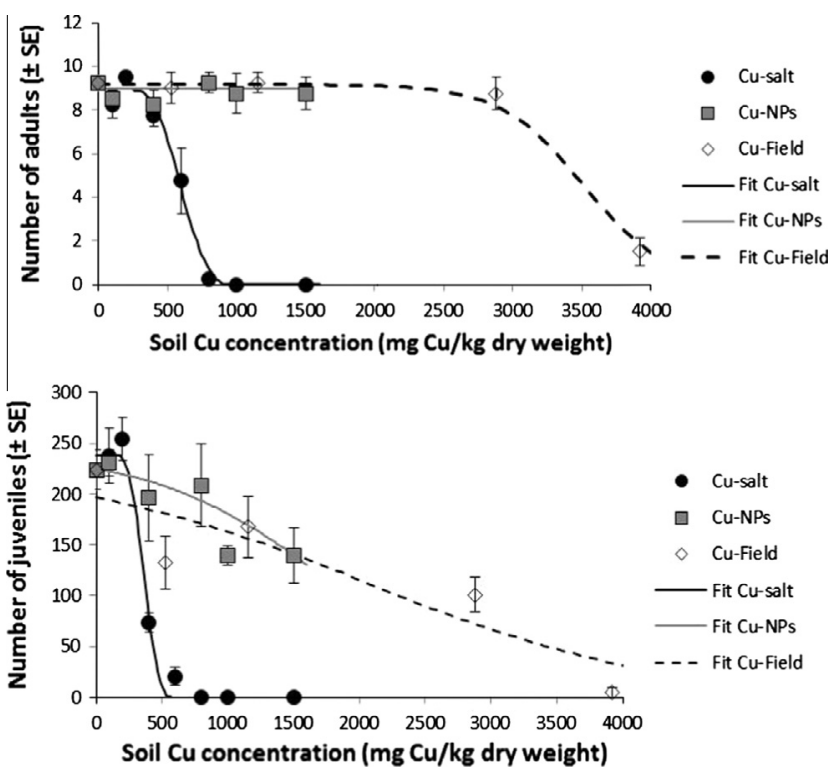

Fig. 4. Effects of copper nitrate (Cu-salt), copper nanoparticles (Cu-NPs) and historically Cu-salt contaminated field soil (Cu-field) on survival (up) and reproduction (down) on Enchytraeus crypticus. Results are expressed as average $(\mathrm{AV}) \pm$ standard error (SE); $n=4$. The fitted lines are the models (threshold sigmoid) used to estimate $\mathrm{EC}_{x}$ values, see Table 1.

combined with an only partial oxidation of the nanoparticles. The study also show that spiking soils with $\mathrm{CuNO}_{3}$ does not provide an exposure scenario (based on chemical measures) similar to that of field contaminated soil, in the latter soil the long-term development of the soil incorporates the $\mathrm{Cu}$ to less extractable fractions.

The XANES observations indicated partial oxidation of the $\mathrm{Cu}-\mathrm{NPs}$. Since the $\mathrm{Cu}-\mathrm{NPs}$ soil spectra resemble that of a non-soil
$25 \mathrm{~nm}$ particle [more similar than the non-soil $80 \mathrm{~nm}$ spectra] the observations suggests that the NPs were present as smaller and more oxidized particles in the soil matrix. This is in agreement with Unrine et al. (2010), who observed partial oxidation of Cu-NPs (32 and $102 \mathrm{~nm}$ ) in OECD soil. Within the Cu-NPs spiked soil, the XANES spectra shows approximately $42 \% \mathrm{Cu}$ oxidation, i.e. $10 \%$ $\mathrm{Cu}(\mathrm{I})$ and $32 \% \mathrm{Cu}(\mathrm{II})$. Considering that there was a sixfold difference in toxicity between $\mathrm{Cu}$-salt and $\mathrm{Cu}-\mathrm{NPs}$ exposure a $17 \%$ release would be enough for the toxicity in the Cu-NPs to be explained by released $\mathrm{Cu}^{2+}$. Possible released ions must have been immediately bound in the soil matrix, since there was no measurable Cu-activity in the soil-solution (detection limit $10^{-9}$, ion selective Cu-activity). However, since there was also no measurable $\mathrm{Cu}$-activity when adding $\mathrm{Cu}$-NPs to the modified-water (same ionic strength and $\mathrm{pH}$ as the soil-solution), the release of $\mathrm{Cu}$ from $\mathrm{Cu}-\mathrm{NPs}$ seems limited despite oxidation of the particle surface. The sequential extraction showed that $\mathrm{Cu}$ from both $\mathrm{Cu}-\mathrm{NPs}$ and $\mathrm{Cu}$-salt are in relative loosely bound fractions (first extraction), which correspond to the higher toxicity in these soils compared to Cu-field soil. This first extraction probably covers Cu specifically sorbed on surfaces of clays, $\mathrm{OM}, \mathrm{Fe} / \mathrm{Mn}$ oxyhydrooxides and to some degree silicates (Gleyzes et al., 2002), whereas the next extraction covers $\mathrm{Cu}$ bound in Fe- and Mn-oxides. The Cu-NPs are a little less extractable in 1 st extraction (5\% difference) than Cu-salt indicating a little stronger binding of $\mathrm{Cu}-\mathrm{NPs}$ in soil i.e. equivalent to a higher $K_{d}$. For the field contaminated soil, a larger fraction remained in the residual fraction (believed to be less bio-available) which corresponded to a lower toxicity in this soil. A concern with the sequential extraction procedure is that it could have in itself influenced Cu-NPs e.g. dissolving them causing the measurement to reflect free ions and not the particles behavior. The 1st extraction, a weak acid, probably did not increase dissolution since it is also used as a capping agent in NPs, e.g. Ag-NPs (see e.g. Deng et al., 2013), the reducing power of hydroxylammonium 
be found, in the online version, at http://dx.doi.org/10.1016/j. chemosphere.2015.06.045. rather reduce $\mathrm{Cu}(\mathrm{I}$ and $\mathrm{II})$ to $\mathrm{Cu}(0)$ during the extraction process. The final extraction(3rd extraction) using hydrogen peroxide likely oxidizes the nanoparticles to $\mathrm{Cu}$ I or II. Hence, the first two extractions probably reflect the particle behavior, whereas the third reflected the free-ions. Given this, the exposure measures indicated that the enchytraeids in the Cu-NPs contaminated soil were partly exposed to $\mathrm{Cu}$ in the form of nanoparticles and less [in terms of total-concentration (weight)] to the released dissolved $\mathrm{Cu}^{2+}$ ions.

Hence, the chemical analyses supported that the $\mathrm{Cu}$-salt and the $\mathrm{Cu}$-field toxicity was related to the availability of $\mathrm{Cu}^{2+}$, and that even the organisms ingest soils they do not extracted the harder bounded $\mathrm{Cu}$ fraction. For the $\mathrm{Cu}-\mathrm{NPs}$ exposure the toxicity was probably due to both nanoparticles and $\mathrm{Cu}^{2+}$ toxicity, although released ions (ca. 20\% released) may also explain toxicity. At the same time, and assuming that particles are causing the toxicity, then a slower uptake-rate could explain the observed toxicity differences. This would also fit with all the exposure measurements, i.e. primary oxidation state of 0 in the soil (with oxidation state I and II still associated with the particle), low $\mathrm{Cu}^{2+}$ activity in the soil-solution and a similar distribution in the sequential extraction (the toxicity could be expressed based on the first extraction which would overlap the differences). This is well in line with the organisms' uptake mechanisms, i.e. both adsorption of via the body surface and ingestion of soil particles occurs. Adsorption would occur from the water soil biofilm and mostly for the bioavailable ionic fraction, whereas soil ingestion would include both readily and less bioavailable fraction. Once inside the organisms' gut the soil bounded Cu-NPs can be released at a slower rate. Given this, $\mathrm{Cu}-\mathrm{NPs}$ would simply be less toxic (than free ions) during a 3 week exposure, with the Cu-NPs toxicity becoming expressed over longer exposure time.

\section{Conclusions}

The three Cu-exposure scenarios used showed induced toxicity at different levels. The freshly spiked Cu-salt was the most toxic for reproductive output of the worms, followed by $\mathrm{Cu}-\mathrm{NPs}$ and then $\mathrm{Cu}$-field. XANES indicated only one oxidation state (II) in Cu-salt and $\mathrm{Cu}$-field soil, whereas in $\mathrm{Cu}-\mathrm{NPs}$ soil it was present in all oxidation states $(0, \mathrm{I}$ and $\mathrm{II})$. The Cu-NPs became partially oxidized in soil, but only a limited dissolution occurred.

\section{Acknowledgments}

Portions of this research were carried out at Beamlines X1 and C of the DORIS light source at DESY. DESY is a member of the Helmholtz Association (HGF). The project was financially supported by the funding FEDER through COMPETE-Programa Operacional Factores de Competitividade, by National funding through FCT-Fundação para a Ciência e Tecnologia, within the research project NANOkA FCOMP-01-0124- FEDER-008944 (Ref ${ }^{\text {. }}$. FCT PTDC/BIA-BEC/103716/2008), and through an FCT PhD grant to Susana Gomes (SFRH/BD/63261/2009), the Nordic Council Grant project (1928 (1599)), the FP7 projects MARINA (263215) and SUN (604305). The authors report no conflict of interest. The authors alone are responsible for the content and writing of the paper.

\section{Appendix A. Supplementary material}

Supplementary data is available with calculations, derivations and additional graphs for XANES measurements (see relevance in main text). Supplementary data associated with this article can

\section{References}

Amorim, M.J.B., Scott-Fordsmand, J.J., 2012. Toxicity of copper nanoparticles and $\mathrm{CuCl}_{2}$ salt to Enchytraeus albidus worms: survival, reproduction and avoidance responses. Environ. Pollut. 164, 164-168. http://dx.doi.org/10.1016/ j.envpol.2012.01.015.

Amorim, M.J.B., Rombke, J., Schallna, H.J., Soares, A.M.V.M., 2005. Effect of soil properties and aging on the toxicity of copper for Enchytraeus albidus, Enchytraeus luxuriosus, and Folsomia candida. Environ. Toxicol. Chem. 24 1875-1885.

Amorim, M.J.B., Novais, S., Rombke, J., Soares, A.M.V.M., 2008. Enchytraeus albidus (Enchytraeidae): A test organism in a standardised avoidance test? Effects of different chemical substances. Environ. Int. 34, 363-371. http://dx.doi.org/ 10.1016/j.envint.2007.08.010.

Amorim, M.J.B., Gomes, S.I.L., Soares, A.M.V.M., Scott-Fordsmand, J.J., 2012. Energy basal levels and allocation among lipids, proteins, and carbohydrates in Enchytraeus albidus: changes related to exposure to $\mathrm{Cu}$ salt and $\mathrm{Cu}$ nanoparticles. Water, Air, Soil Pollut. 223, 477-482. http://dx.doi.org/10.1007/ s11270-011-0867-9.

Batsmanova, L.M., Gonchar, L.M., Taran, N.Y., Okanenko, A.A., 2013. Using a colloida solution of metal nanoparticles as micronutrient fertiliser for cereals. Proc. Int. Conf. Nanomater. Appl. Prop.

Belli, B., 2012. Eating Nano|EMagazine.com [WWW Document]. <http://www emagazine.com/magazine/eating-nano> (accessed 5.19.15).

Deng, D., Jin, Y., Cheng, Y., Qi, T., Xiao, F., 2013. Copper nanoparticles: aqueous phase synthesis and conductive films fabrication at low sintering temperature. ACS Appl. Mater. Interfaces 5, 3839-3846. http://dx.doi.org/10.1021/am400480k.

Evans, P., Matsunaga, H., Kiguchi, M., 2008. Large-scale application of nanotechnology for wood protection. Nat. Nanotechnol. 3, 577. http:// dx.doi.org/10.1038/nnano.2008.286.

Gleyzes, C., Tellier, S., Astruc, M., 2002. Fractionation studies of trace elements in contaminated soils and sediments: a review of sequential extraction procedures. Trac-Trends Anal. Chem. 21, 451-467. http://dx.doi.org/10.1016/ S0165-9936(02)00603-9.

Gomes, S.I.L., Novais, S.C., Gravato, C., Guilhermino, L., Scott-Fordsmand, J.J., Soares, A.M.V.M., Amorim, M.J.B., 2012a. Effect of Cu-nanoparticles versus one Cu-salt: analysis of stress and neuromuscular biomarkers response in Enchytraeus albidus (Oligochaeta). Nanotoxicology 6, 134-143. http://dx.doi.org/10.3109/ 17435390.2011 .562327$.

Gomes, S.I.L., Novais, S.C., Scott-Fordsmand, J.J., De Coen, W., Soares, A.M.V.M., Amorim, M.J.B., 2012b. Effect of Cu-nanoparticles versus Cu-salt in Enchytraeus albidus (Oligochaeta): differential gene expression through microarray analysis. Comp. Biochem. Physiol. Part C 155, 219-227. http://dx.doi.org/10.1016/ j.cbpc.2011.08.008.

Heckmann, L.-H., Hovgaard, M.B., Sutherland, D.S., Autrup, H., Besenbacher, F. Scott-Fordsmand, J.J., 2011. Limit-test toxicity screening of selected inorganic nanoparticles to the earthworm Eisenia fetida. Ecotoxicology 20 (1), 226-233. http://dx.doi.org/10.1007/s10646-010-0574-0.

Jansch, S., Rombke, J., Didden, W., 2005. The use of enchytraeids in ecological soil classification and assessment concepts. Ecotoxicol. Environ. Saf. 62 266-277.

Llorens, A., Lloret, E., Picouet, P.A., Trbojevich, R., Fernandez, A., 2012. Metallic based micro and nanocomposites in food contact materials and active food packaging. Trends Food Sci. Technol. http://dx.doi.org/10.1016/ j.tifs.2011.10.001.

Løkke, H., Van Gestel, C. (Eds.), 1998. Handbook of Soil Invertebrate Toxicity Tests. John Wiley \& Sons, Chichester.

Maraldo, K., Christensen, B., Strandberg, B., Holmstrup, M., 2006. Effects of copper on enchytraeids in the field under differing soil moisture regimes. Environ. Toxicol. Chem. 25, 604-612.

Menezes-Oliveira, V.B., Scott-Fordsmand, J.J., Rocco, A., Soares, A.M.V.M., Amorim, M.J.B., 2011. Interaction between density and $\mathrm{Cu}$ toxicity for Enchytraeus crypticus and Eisenia fetida reflecting field scenarios. Sci. Total Environ. 409, 3370-3374. http://dx.doi.org/10.1016/j.scitotenv.2011.04.033.

OECD, 2004. Guidelines for the testing of chemicals No. 220. Enchytraeid Reproduction Test. Organization for Economic Cooperation and Development. Paris, France.

Peijnenburg, W., Capri, E., Kula, C., Liess, M., Luttik, R., Montforts, M., Nienstedt, K. Römbke, J., Sousa, J.P., Jensen, J., 2012. Evaluation of exposure metrics for effect assessment of soil invertebrates. Crit. Rev. Environ. Sci. Technol. http:/ dx.doi.org/10.1080/10643389.2011.574100.

Rauret, G., Lopez-Sanchez, J.F., Sahuquillo, A., Rubio, R., Davidson, C., Ure, A. Quevauviller, P., 1999. Improvement of the BCR three step sequential extraction procedure prior to the certification of new sediment and soil reference materials. J. Environ. Monit. 1, 57-61.

Ravel, B., Newville, M., 2005. ATHENA, ARTEMIS, HEPHAESTUS: data analysis for Xray absorption spectroscopy using IFEFFIT. J. Synchrotron Radiat. 12, 537-541.

Scott-Fordsmand, J.J., Krogh, P.H., Weeks, J.M., 2000a. Responses of Folsomia fimetaria (Collembola : Isotomidae) to copper under different soil copper contamination histories in relation to risk assessment. Environ. Toxicol. Chem. 19, 1297-1303. http://dx.doi.org/10.1002/etc.5620190511. http://dx.doi.org/10.1107/S0909049505012719. 
Scott-Fordsmand, J.J., Weeks, J.M., Hopkin, S.P., 2000b. Importance of contamination history for understanding toxicity of copper to earthworm Eisenia fetida (Oligochaeta: Annelida), using neutral-red retention assay. Environ. Toxicol. Chem. 19, 1774-1780.

SigmaPlot 11.0, 2009. Copyright (c) Systat Software Inc.
Unrine, J.M., Tsyusko, O.V., Hunyadi, S.E., Judy, J.D., Bertsch, P.M., 2010. Effects of particle size on chemical speciation and bioavailability of copper to earthworms (Eisenia fetida) exposed to copper nanoparticles. J. Environ. Qual. 39, 19421953. http://dx.doi.org/10.2134/jeq2009.0387. 